\title{
EFFECT OF FEEDING (Moringa oleifera) LEAF MEAL ON QUAIL PERFORMANCE UNDER NORTH SINAI CONDITIONS
}

\author{
Mohamed M. El-Kashef ${ }^{1}$, M.A. Abdel Ghaffar ${ }^{1}$, H.A. Khalil ${ }^{2}$ and A.M. Ali ${ }^{1}$
}

1. Dept. Anim. and Poult. Prod., Fac. Environ. Agric. Sci., Arish Univ., Egypt.

2. Dept. Anim. Prod., Fac. Agric., Suez Canal Univ., Ismailia, Egypt.

\begin{abstract}
The present study was carried out in the farm of the Department of Animal and Poultry Production, Faculty of Environmental Agricultural Sciences, Arish University. This study was carried out to investigate the effect of supplementing Moringa oleifera leaf meal (MOLM) on the growth performance and blood biochemical parameters of growing quails. A total of 180 seven days, unsexed quail chicks were randomly divided into four experimental groups. Each group was further subdivided into 3 replicates, 15 chicks per each. Four levels of MOLM $(0.0,0.2,0.4$ and $0.6 \%)$ were used during the experimental period from 7 to 42 day of age. The results showed that final body weight and body weight gain were increased significantly $(\mathrm{P}<0.05)$ at the $0.2 \%$ level of MOLM; also, feed intake had the same trend, however, there is no significant effect on feed conversion values among treatments. The levels of MOLM significantly increased dressing percentage, head, liver, heart, gizzard and total edible parts weight except $0.6 \%$ level of MOLM. Blood globulin and albumin increased significantly $(\mathrm{P}<0.05)$ with increasing the level of MOLM. Total protein was not affected by inclusion of MOLM in quail diets. Plasma cholesterol had lower level in all treatments compared to control. In addition, HDL fraction was increased, while LDL decreased significantly in all treatments compared to control group. However, Plasma AST and ALT decreased at all levels of MOLM compared to control group.It could be concluded that addition of Moringaoleifera meal leaves up to $0.2 \%$ improved growth performance, carcass characteristics and blood parameters of the quail chicks.
\end{abstract}

Key word: Quail chicks, Moringa oleifera leaves, productive performance, carcass characteristics, blood parameters.

\section{INTRODUCTION}

Antibiotic as growth promoters have been used as a feed additive in poultry industry to enhance gut health and to control sub-clinical diseases. Recently, use of antibiotics in poultry feeding can increase risk of antibiotic resistance in human society, therefore in some countries, such as the Europe Union, use of antibiotic as feed additive has been banned (Lee $\boldsymbol{e t}$ al., 2004). So, we need to quickly replace antibiotics as feed additive with other options. These new options should be inexpensive and available in everywhere as well as healthy for human socitey. There are some alternatives to in-feed antibiotics such as fibre-degrading enzymes, prebiotics, probiotics, mannan oligosaccharides, symbiotics and phytobiotics or medicinal plants (Yang et al., 2009; Ahmadiet al., 2013).

Moringaoleifera is one of such plant that has been identified to contain natural antioxidants (Siddhuraju and Becker, 2003). Moreover, the antioxidant effect of

\footnotetext{
* Correspondence Author: +201069246609

E-mail address: melkashef82@yahoo.com
} 
Moringaoleifera leaves was due to the presence of polyphenols, tannins, anthocyanin, glycosides and thiocarbamates, which remove free radicals, activate antioxidant enzymes and inhibit oxidases (Luqmanset al., 2012). Moringa leaves can serve as a rich source of $\beta$-carotene, vitamins $\mathrm{C}$ and $\mathrm{E}$ and polyphenolics. The growing popularity of the use of Moringa oleifera as a feed additive in poultry feeding necessitates through investigation into its nutritional value, as well its impact on haematological parameters as a measure of both nutritional and medicinal benefits of the leaves in broiler chicks (Ebenebe et al., 2012). Although, several studies have reported the use of Moringa oleifera leaves as feed supplements in livestock (Ayssiwede et al., 2011 and Nkukwana et al., 2014).

Therefore, the objective of the present study was to evaluate the beneficial effects of using Moringaoleifera leaf meal as a growth promoter on the growth performance and carcass quality of quail chicks under Sinai conditions.

\section{MATERIALS AND METHODS}

\section{Study Area}

The study was carried out at the farm of the Dept. Anim. and Poult. Prod., Fac. Environ. Agric. Sci., Arish Univ., El-Arish, North Sinai, Egypt. El-Arish is located at latitude 31.27 North and longitude 33.75 East (Google maps, 2016).

\section{Experimental Birds}

One hundred and eighty; seven day old chicks having nearly equaled live weight (33 g) were used for the study after being left on the experimental site for a period of one week to acclimatize. The chicks were randomly assigned to four dietary treatments, such that there were 45 birds per treatment and each treatment had three replicates with 15 chicks per replicate. The birds were managed on batteries provided with appropriate experimental diets daily and allowed to feed ad libitum, clean water was also provided daily. The chicks were subjected to similar conditions of management and sanitary conditions throughout the period of the experiment.

\section{Experimental Diets}

Moringa leaves used in the preparation for the three experimental diets were purchased from the local farmer. The leaves were spread to dry under shade for two weeks thereafter; dried under a constant temperature of $30^{\circ} \mathrm{C}$ for 30 minutes in an oven to make them crispy for easy blending. Later milled with a hammer mill and sieved with $3 \mathrm{~mm}$ mesh and stored in a well tight polyethylene bags at room temperature $25^{\circ} \mathrm{C}$.

All diets met the nutrient requirements of quail as set out by NRC (1994). Table 1 represents the ingredients composition and calculated analysis of the experimental diets.

Performance characteristics monitored included initial body weight, final body weight, body weight gain, total feed intake and feed conversion. At the end of the experimental period 42 day, 9 birds from each treatment, being three birds from each replicate had been deprived from feed for 8 hours, then weighed and slaughtered to estimate some carcass characteristics (carcass, head, liver, heart, gizzard and giblets). Blood samples were taken to determine serum content of total protein, albumin, globulin, glucose, total lipids, low density lipoprotein (LDL), highdensity lipoprotein (HDL), cholesterol, and liver enzymatic activity (AST and ALT) using commercial kits. Value of globulin was calculated by subtracting the value of albumin from the value of total protein. Albumin/globulin ratio $(\mathrm{A} / \mathrm{G})$ was calculated according to results of albumin and globulin. 
SINAI Journal of Applied Sciences (ISSN: 2314-6079) Vol. (6) Is. (2), Aug. 2017

Table (1): The composition and calculated analysis of experimental diets.

\begin{tabular}{lcccc}
\hline Ingredients (\%) & Control & \multicolumn{3}{c}{ Moringaoleifera leave meal (\%) } \\
\cline { 3 - 5 } & & $\mathbf{0 . 2}$ & $\mathbf{0 . 4}$ & $\mathbf{0 . 6}$ \\
\hline Yellow corn & 55.78 & 55.87 & 55.96 & 56.05 \\
Soybean meal & 33.67 & 33.53 & 33.39 & 33.25 \\
Corn gluten meal & 7.30 & 7.30 & 7.30 & 7.30 \\
Di-calcium phosphate & 0.80 & 0.80 & 0.80 & 0.80 \\
Limestone & 1.58 & 1.43 & 1.28 & 1.18 \\
Salt & 0.35 & 0.35 & 0.35 & 0.30 \\
(V\&M.) Premix* & 0.39 & 0.3 & 0.30 & 0.30 \\
DL. Methionine & 0.11 & 0.11 & 0.11 & 0.11 \\
L. Lysine & 0.11 & 0.11 & 0.11 & 0.11 \\
MOLM & - & 0.20 & 0.40 & 0.60 \\
Total & $100 \%$ & $100 \%$ & $100 \%$ & $100 \%$ \\
\hline Calculated analysis (\%) & \multicolumn{3}{c}{$\%$} \\
\hline Crude protein & 24 & 24 & 24 & 24 \\
ME Kcal/Kg & 2900 & 2900 & 2900 & 2900 \\
Calcium & 0.9 & 0.9 & 0.83 & 0.8 \\
AV. Phosphorus & 0.4 & 0.4 & 0.4 & 0.39 \\
L. Lysine & 1.23 & 1.23 & 1.23 & 1.22 \\
DL. Methionine & 0.46 & 0.46 & 0.46 & 0.46 \\
\hline
\end{tabular}

\section{Economical Evaluation}

The prevailing market prices of ingredients and Moringaoleifera plant used during the period of the study were used for the economic appraisal of the feeds. Economical efficiency is defined as the net revenue per unit feed cost calculated from input output analysis as described by Asar et al., (2010).

The economic efficiency was calculated as the following

- Feed cost $=$ number of $\mathrm{kg}$ feed per quail $\mathrm{X}$ price of $\mathrm{kg}$ feed.

- Selling revenue $=$ body weight per quail $\mathrm{X}$ price of $\mathrm{kg}$ for live body weight.

- Net revenue $=$ difference between selling revenue and feed cost.

- E.E.F (Economic efficiency) = (net revenue / feed cost $) \times 100$.

- R.E.E (Relative economic efficiency), assuming control treatment $=100 \%$.

\section{Statistical Analysis}

The obtained data was statistically analyzed using one-way analysis of the general linear model procedure described in SAS User's Guide (SAS., 2004). Differences among means were tested using Duncan's multiple range test (Duncan, 1955).

\section{RESULTS AND DISCUSSION}

\section{Growth performance}

The effect of feeding different levels of Moringaoleifera leaf meal on growth performance are shown in Table 2. The results indicated that quail birds fed diet supplemented with $0.2 \%$ Moringaoleifera leaf meal had significantly $(\mathrm{P} \leq 0.05)$ the highest final body weight and body weight (BW) gain BWG (281.2 and $274.2 \mathrm{~g})$ compared with the control and other treatment groups. The lowest final body weight and body weight gain (248.30 and 241.30 g) were observed in birds fed high level $(0.6 \%)$ of Moringaoleifera leaf compared with control and other treatments. 
Table (2): Effect of dietary Moringaoleifera leaf meal on growth performance of Japanese quail.

\begin{tabular}{ccccc}
\hline \multirow{2}{*}{ Traits } & \multirow{2}{*}{ Control } & \multicolumn{3}{c}{ Moringa oleifera leaf meal (\%) } \\
\cline { 3 - 5 } & & $\mathbf{0 . 2}$ & $\mathbf{0 . 4}$ & $\mathbf{0 . 6}$ \\
\hline Initial body weight $(\mathbf{g})$ & $33.00^{\mathrm{a}} \pm 0.00$ & $33.00^{\mathrm{a}} \pm 0.00$ & $33.00^{\mathrm{a}} \pm 0.00$ & $33.00^{\mathrm{a}} \pm 0.00$ \\
Final body weight $(\mathbf{g})$ & $253.65^{\mathrm{c}} \pm 1.08$ & $281.20^{\mathrm{a}} \pm 1.42$ & $275.42^{\mathrm{b}} \pm 0.42$ & $248.30^{\mathrm{d}} \pm 1.48$ \\
Body weight gain $(\mathbf{g})$ & $246.65^{\mathrm{c}} \pm 1.08$ & $274.20^{\mathrm{a}} \pm 1.42$ & $268.42^{\mathrm{b}} \pm 0.42$ & $241.30^{\mathrm{d}} \pm 1.48$ \\
Total feed intake (g) & $554.16^{\mathrm{b}} \pm 5.86$ & $622.77^{\mathrm{a}} \pm 1.26$ & $612.88^{\mathrm{a}} \pm 1.49$ & $547.73^{\mathrm{b}} \pm 5.02$ \\
Feed conversion $(\mathbf{g} / \mathbf{g})$ & $2.25^{\mathrm{a}} \pm 0.02$ & $2.27^{\mathrm{a}} \pm 0.01$ & $2.23^{\mathrm{a}} \pm 0.02$ & $2.27^{\mathrm{a}} \pm 0.05$ \\
\hline
\end{tabular}

$\mathrm{a}, \mathrm{b}, \mathrm{c}$ Means in the same row with different superscripts are significantly different $(\mathrm{p}<0.05)$.

This study confirms previous findings indicated that Moringa Leaf Meal promoted good growth and productivity in poultry which is attributed to its nutrients and phytochemicals and antimicrobial properties (Fahey et al., 2001; Kakengi et al., 2007).

Also, the improvement in final body weight and body weight gain could be attributed to high digestibility of Moringa leaves (Backer, 1995) which could improve absorption of nutrients. The rich content of nutrients (Fahey et al., 2001) and antimicrobial properties of Moringa (Kakengi et al., 2007) may be responsible for these findings. Moringa oleifera was also reported to have a natural enzyme which aid in digestion of fibrous food in animals (Backer, 1995) .These results are in harmony with the finding of KoutElkloubet al. (2015). who mentioned that the inclusion of Moringa oleifera leaves meal with $0.2,0.4$ and $0.6 \%$ levels in the diet of the growing Japanese quails significantly $(\mathrm{P}<0.05)$ enhanced their final body weight and body weight gain compared with control group.

In this respect, Banjo (2012) found that broilers fed diet supplemented with $1 \%$ Moringa had significantly higher final body weight and body weight gain than the control. Also, Dey and De (2013) found that using 0.25 or $0.40 \%$ MOLM in broiler diets gave a significant $(\mathrm{P}<0.01)$ improvement in BW compared to control. Teteh et al. (2013) showed that overall chick weights and daily BWG increased significantly with age $(\mathrm{P}<0.05)$ when used 1 and $2 \%$ MOLM compared to the control group. On the contrary, Mahmud et al. (2016) found that no significant difference was observed in the mean body weight gain of quail birds fed different levels of MOLM as partial from soybean.

Also, Makanjuola et al. (2014) indicated that adding MOLM at $0.2,0.4$ and $0.6 \%$ to the diets lasted 28 days, had no adverse effect on final weight and body weight gain in broiler chicken. Along the same line, Paguia et al. (2014) found that using 0.20, $0.30,0.40$ and $0.50 \%$ MOLM in broiler diets did not $(\mathrm{P}<0.05)$ significantly influence the broilers BW and BWG.

The effect of feeding different levels of Moringaoleifera leaf meal on feed intake and feed conversion are shown in Table 2. The average feed consumption during experiment period (42 day of age) was significantly higher (622.77 and $612.88 \mathrm{~g}$ ) in 0.2 and $0.4 \%$ Moringaoleifera leaf meal group, respectively compared to control and $0.6 \%$ group (554.16 and 547.73g), respectively. These results agree with those obtained by of KoutElkloub et al. (2015) who showed that using $0.2 \%$ Moringaoleifera leaf meal in quail diet significantly increased 
feed intake compared with control group. Also, Banjo (2012) showed that using 0, 1 , 2 and 3\% MOLM in broiler diet significantly increased feed intake up to $2 \%$ MLOM. Furthermore, Dey and De (2013) reported that MOLM supplementation into broiler diets at levels of 0.25 or $0.40 \%$ significantly $(\mathrm{P}<0.01)$ increased the feed intake compared to control.

For fed conversion ratio (FCR), same results were obtained by Mahmud et al. (2016) who found that no significant difference in the FCR quail birds fed different levels of MOLM as partial from soybean. Also, Nkukwana et al. (2014) found that no significant differences were observed in feed intake between treatments during periods from 0 to 21 day and 0 to 35 day while, FCR was the highest $(\mathrm{P}<0.05)$ in birds supplemented with MOLM, except for 3, 9 and $15 \mathrm{~g} / \mathrm{kg}$. Paguia et al. (2014) found that using $0.20,0.30,0.40$ and $0.50 \%$ MOLM in broiler diets did not significantly $(\mathrm{P}<0.05)$ influence the broilers feed consumption and FCR.

On the other hand, KoutElkloub et al. (2015) found that the inclusion of Moringaoleifera leaf meal with $0.2 \%$ in the diet of the growing Japanese quails significantly $(\mathrm{P}<0.05)$ enhanced feed conversion compared with control group. In this respect Ebenebe et al. (2012) reported that, chicks fed on Moringa based diets performed significantly $(\mathrm{P}<0.05)$ better than the birds of control group regarding FCR. Banjo (2012) showed that using 0, 1, 2 and $3 \%$ MOLM in broiler diet significantly increased feed intake up to $2 \%$ MLOM, on the other hand, the different levels of MOLM recorded significantly the best FCR than control group.

\section{Carcass characteristics}

Statistical analysis of carcass yield in different groups are illustrated in Table 3. Quail birds feed diet supplemented with
$0.20 \%$ of MOLM, had significantly $(\mathrm{P}<0.05)$ higher dressing percentage and total edible parts compared to control and other treatments. On the other side, birds fed diet supplemented with 0.20 or $0.40 \%$ of MOLM had significantly $(\mathrm{P}<0.05)$ higher head, liver, heart, gizzard and giblet weight compared to control and $0.6 \%$ groups. In this respect, Karthivashan et al. (2015) found that broiler feed supplemented with $0,0.5,1.0$, and $1.5 \%$ of MOLM extracts, had significantly $(\mathrm{P}<0.05)$ higher dressing percentage compared to broilers fed control.

Also, David et al. (2012) found that $0.1 \%$ Moringa leaf powder or $0.1 \%$ Moringa fruit powder, had significantly $(\mathrm{P}<0.05)$ improved dressing percentage compared to the negative control. On contrary, KoutElkloub et al. (2015) observed no significant effect due to inclusion Moringaoleifera leaf meal at 0.20, 0.40 and $0.60 \%$ levels in quail diets on dressing percentage, head, liver, heart, gizzard and giblet weight. Also, Ologhobo et al. (2014) concluded that, feeding MOLM at 0.2, 0.4 and $0.6 \%$ levels had no negative influence on the carcass quality but rather improved the breast and drumstick weight of broiler chicks.

\section{Blood constituents}

The effects of dietary treatments on blood constituents at 42 day old quail are shown in Table 3. Addition of MOLM $(0.20-0.60 \%)$ to quail birds diets had no significant effects on blood total protein, total lipid, LDL and HDL cholesterol.

The dietary inclusion $0.20 \%$ of MOLM on plasma constituents led to significant improvements in plasma globulin compared with control group. However, the control group had the highest albumin and $\mathrm{A} / \mathrm{G}$ compared with the other treatment groups. The lowest albumin value was observed in group fed diet supplemented with $0.60 \%$ MOLM. 
Table (3): Effect of dietary Moringa oleifera leaf meal on carcass characteristics of quail at 42 days old.

\begin{tabular}{ccccc}
\hline \multirow{2}{*}{ Trait } & \multirow{2}{*}{ Control } & \multicolumn{3}{c}{ Moringaoleifera leaf meal (\%) } \\
\cline { 3 - 5 } & $250.00^{\mathrm{b}} \pm 0.97$ & $279.56^{\mathrm{a}} \pm 1.39$ & $277.89^{\mathrm{a}} \pm 1.18$ & $249.67^{\mathrm{b}} \pm 1.20$ \\
\hline Live weight(g) & $73.33^{\mathrm{c}} \pm 0.19$ & $78.29^{\mathrm{a}} \pm 0.18$ & $76.92^{\mathrm{b}} \pm 0.33$ & $73.39^{\mathrm{c}} \pm 0.13$ \\
Dressing \% & $10.08^{\mathrm{b}} \pm 0.01$ & $10.32^{\mathrm{a}} \pm 0.02$ & $10.31^{\mathrm{a}} \pm 0.03$ & $10.28^{\mathrm{a}} \pm 0.02$ \\
Head (g) & $5.48^{\mathrm{b}} \pm 0.03$ & $6.19^{\mathrm{a}} \pm 0.01$ & $6.20^{\mathrm{a}} \pm 0.02$ & $5.51^{\mathrm{b}} \pm 0.11$ \\
Liver (g) & $2.16^{\mathrm{b}} \pm 0.06$ & $2.73^{\mathrm{a}} \pm 0.02$ & $2.72^{\mathrm{a}} \pm 0.01$ & $2.07^{\mathrm{b}} \pm 0.08$ \\
Heart (g) & $4.20^{\mathrm{b}} \pm 0.03$ & $4.87^{\mathrm{a}} \pm 0.01$ & $4.88^{\mathrm{a}} \pm 0.02$ & $4.19^{\mathrm{b}} \pm 0.11$ \\
Gizzard (g) & $11.84^{\mathrm{b}} \pm 0.04$ & $13.79^{\mathrm{a}} \pm 0.04$ & $13.81^{\mathrm{a}} \pm 0.05$ & $11.77^{\mathrm{b}} \pm 0.22$ \\
Giblets *(g) & $195.17^{\mathrm{c}} \pm 0.72$ & $232.68^{\mathrm{a}} \pm 1.44$ & $227.58^{\mathrm{b}} \pm 1.50$ & $195.00^{\mathrm{c}} \pm 0.93$ \\
\hline Total edible parts*** & $(\mathbf{g})$ &
\end{tabular}

$\mathrm{a}, \mathrm{b}, \mathrm{c}$ Means in the same row with different superscripts are significantly different $(\mathrm{p}<0.05)$.

$*$ giblets $=$ gizzard $=$ liver $=$ heart. $\quad * *$ Total edible parts $=$ dressing + giblets.

The same line Hassan (2016) who found that the plasma globulin increased significantly $(p<0.05)$ with increasing the level of MOLM up to $0.30 \%$. While, albumin did not affected $(\mathrm{P}<0.05)$ with increasing the level of MOLM to 0.30. On contrary, Makanjuola et al. (2014) found that the use of $0.2,0.4$ and $0.6 \%$ MOLM did not influence the serum total protein, albumin, globulin and blood cholesterol and LDL-cholesterol had lower level in all treatments compared to control.

These results could be evidence of the effect of MOLM on plasma cholesterol and LDL-cholesterol reduction. The best level of MOLM was $0.2 \%$ which recorded decrease in plasma cholesterol and LDLcholesterol compared to control group. Similar results have been obtained by KoutElkloub et al. (2015) who found that birds fed diet supplemented with $0.20 \%$ MOLM had lowest total cholesterol, triglyceride, LDL-cholesterol compared with control group. Also, Dey and De (2013) found that using 0.25 or $0.40 \%$ MOLM in broiler diets was significant $(\mathrm{P}<$ 0.01) reduced in total cholesterol, triglyceride, LDL-cholesterol and increased HDL-cholesterol in MOLM supplemented birds. Blood glucose significantly increased in birds fed diet supplemented with $0.40 \%$ MOLM compared with the control group.
On contrary, Jaiswal et al. (2009), reported that blood glucose leveldecreased after administration of Moringaoleifera aqueous leaf extract to rats. Blood AST and ALT decreased with all levels of MOLM. Since liver is reported to contain enzymes like ALT and AST, it releases these enzymes to the blood when damaged (Kaplan et al., 2003). The decrease in ALT and AST activity observed in birds on diet contained $0.2,0.4$ and $0.6 \% \mathrm{MOLM}$ could suggest that MOLM has properties that can enhance liver health. Those results are in the same tone with Kout Elkloub et al. (2015) who found that birds fed diet supplemented with $0.20,0.4$ and $0.6 \%$ MOLM had lowest ALT and AST compared with control group. Also, Hassan (2016) mentioned that the AST decreased significantly $(\mathrm{P}<0.05)$ while, ALT did not affected with adding MOLM levels when broiler chicks fed diets supplemented with $0.1,0.2$ and $0.3 \%$ MOLM.

\section{Economical Evaluation}

Results presented in Table 5 show the economic efficiency of different experimental treatments during experimental period for quail birds. Generally, for overall experimental periods, $0.2 \%$ MOLM showed highest net revenue, economic efficiency and relative economical efficiency followed by $0.4 \%$ MOLM diet then control diet. 
SINAI Journal of Applied Sciences (ISSN: 2314-6079) Vol. (6) Is. (2), Aug. 2017

Table (4): Effect of dietary Moringa oleifera leaf meal on some blood parameters of quail at 42 days old.

\begin{tabular}{lcccc}
\hline \multicolumn{1}{c}{ Traits } & \multirow{2}{*}{ Control } & \multicolumn{3}{c}{ Moringa oleifera leaf meal (\%) } \\
\cline { 3 - 5 } & & $\mathbf{0 . 2}$ & $\mathbf{0 . 4}$ & $\mathbf{0 . 6}$ \\
\hline T. protein (g/dl) & $4.23^{\mathrm{a}} \pm 0.07$ & $4.38^{\mathrm{a}} \pm 0.03$ & $4.21^{\mathrm{a}} \pm 0.12$ & $4.33^{\mathrm{a}} \pm 0.11$ \\
Albumin (A) (g/dl) & $1.71^{\mathrm{a}} \pm 0.14$ & $1.58^{\mathrm{ab}} \pm 0.04$ & $1.43^{\mathrm{ab}} \pm 0.16$ & $1.21^{\mathrm{b}} \pm 0.12$ \\
Globulin (G) (g/dl) & $2.59^{\mathrm{b}} \pm 0.18$ & $3.00^{\mathrm{ab}} \pm 0.03$ & $2.99^{\mathrm{ab}^{\mathrm{a}}} \pm 0.11$ & $3.16^{\mathrm{a}} \pm 0.11$ \\
A/G ratio & $0.67^{\mathrm{a}} \pm 0.10$ & $0.53^{\mathrm{ab}} \pm 0.02$ & $0.48^{\mathrm{ab}^{\mathrm{b}}} \pm 0.07$ & $0.39^{\mathrm{b}} \pm 0.05$ \\
T .lipids (mg/dl) & $460.59^{\mathrm{a}} \pm 6.80$ & $475.52^{\mathrm{a}} \pm 1.58$ & $452.33^{\mathrm{a}} \pm 22.77$ & $431.28^{\mathrm{a}} \pm 23.53$ \\
Glucose (mg/dl) & $155.37^{\mathrm{b}} \pm 0.23$ & $160.94^{\mathrm{ab}} \pm 4.64$ & $171.18^{\mathrm{a}} \pm 2.26$ & $168.30^{\mathrm{ab}} \pm 5.57$ \\
LDL (mg/dl) & $111.83^{\mathrm{a}} \pm 26.37$ & $70.34^{\mathrm{b}} \pm 9.03$ & $85.58^{\mathrm{b}} \pm 1.40$ & $74.95^{\mathrm{b}} \pm 7.39$ \\
HDL (mg/dl) & $64.31^{\mathrm{a}} \pm 12.95$ & $81.76^{\mathrm{a}} \pm 11.45$ & $60.67^{\mathrm{a}} \pm 2.32$ & $73.06^{\mathrm{a}} \pm 7.69$ \\
T. Cholesterol (mg/dl) & $176.14^{\mathrm{a}} \pm 13.44$ & $152.10^{\mathrm{b}} \pm 2.44$ & $146.25^{\mathrm{b}} \pm 1.25$ & $148.00^{\mathrm{b}} \pm 0.42$ \\
ALT U/ L & $44.28^{\mathrm{a}} \pm 1.08$ & $41.50^{\mathrm{ab}} \pm 0.19$ & $40.76^{\mathrm{b}} \pm 0.49$ & $41.08^{\mathrm{b}} \pm 1.18$ \\
AST U/L & $12.26^{\mathrm{a}} \pm 0.16$ & $11.82^{\mathrm{ab}} \pm 0.13$ & $11.38^{\mathrm{b}} \pm 0.13$ & $11.38^{\mathrm{b}} \pm 0.23$ \\
\hline
\end{tabular}

$\mathrm{a}, \mathrm{b}, \mathrm{c}$ Means in the same row with different superscripts are significantly different $(\mathrm{p}<0.05)$.

Table (5): Effect of dietary Moringaoleifera leaf meal on economical evaluation of quail at 42 days old.

\begin{tabular}{ccccc}
\hline \multirow{2}{*}{ Item } & \multirow{2}{*}{ Control } & \multicolumn{3}{c}{ Moringa oleifera leaf meal (\%) } \\
\cline { 3 - 5 } & & $\mathbf{0 . 2}$ & $\mathbf{0 . 4}$ & $\mathbf{0 . 6}$ \\
\hline Feed intake/ bird (Kg.) & 0.554 & 0.623 & 0.613 & 0.548 \\
\hline Final Body weight (g.) & 253.65 & 281.2 & 275.42 & 248.3 \\
\hline Price/Kg feed (L.E) & 4.62 & 4.66 & 4.70 & 4.75 \\
\hline Price of Kg. (L.E) & 28.00 & 28.00 & 28.00 & 28.00 \\
\hline Cost of feed (L.E) & 2.56 & 2.90 & 2.88 & 2.60 \\
\hline Fixed cost ( L.E) & 1.25 & 1.25 & 1.25 & 1.25 \\
\hline Total cost (L.E) & 3.81 & 4.15 & 4.13 & 3.85 \\
\hline Selling revenue (L.E) & 7.10 & 7.87 & 7.71 & 6.95 \\
\hline Net revenue & 3.29 & 3.72 & 3.58 & 3.10 \\
\hline Economic efficiency* & 86.54 & 89.58 & 86.57 & 80.51 \\
\hline Relative economic efficiency** & 100 & 103.52 & 100.04 & 93.03 \\
\hline
\end{tabular}




\section{Conclusion}

It could be concluded that Moringaoleifera leaf meal improved performance, carcass characteristics and blood constituents without any adverse effect. The best level occurred by $0.2 \%$ Moringaoleifera leaf meal in grouping quail diets.

\section{REFERENCES}

Ahmadi, A.; Ebrahimnezhad, Y.; Maheri, Sis.N. and GhiasiGhalehkandi J. (2013). The effects of zinc oxide nanoparticles on performance, digestive organs and serum lipid concentrations in broiler chickens during starter period. Int. J. Biosci., 3 (7): 23-29.

Asar, M.A.; Osman, M.; Yakout, H.M. and Safoat, A. (2010). Utilization of corn-cob meal and fiber bean straw in growing rabbits diets and their effects on performance, digestibility and economical efficiency. Egypt. Poult. Sci., 30 (2): 415 $-442$.

Ayssiwede, S.B.; Dieng, A.; Bello, H.; Chrysostome, C.A.A.M.; Hane, M.B.; Mankor, A.; Dahouda, M.; Houinato, M.R.; Hornick, J.L. and Missohou, A. (2011). Effects of Moringa oleifera (Lam) leaves meal incorporation in diets on growth performance, carcass characteristics and economics results of growing indigenous Senegal chickens. Pak. J. Nutr., 10: 1132-1145.

Backer, K. (1995). Studies on utilization of Moringa oleifera leaves as animal feed. Institute for Animal Production in the Tropics and Subtropics, 480. Univ. Hohenheim Stuttgart, 15.

Banjo, S. (2012). Growth and performance as affected by inclusion of Moringa oleifera leaf meal in broiler chick diet. J. Biol. Agric. Healthcare, 2 (9): 35-38.

David, L.S.; Vidanarachchi, J.K.; Samarasinghe, K.; Cyril, H.W. and Dematawewa, C.M.B. (2012). Effects of Moringa based Feed Additives on the Growth Performance and Carcass Quality of Broiler Chicken. Tropical Agric. Res., 24 (1): 12-20.

Dey, A. and De, P.S. (2013). Infiuence of Moringa oleifera leaves as a functional feed additive on the growth performance, carcass characteristics and serum lipid profile of broiler chicken. Indian $\mathrm{J}$. Anim. Res., 47 (5): 449.

Duncan, D.B. (1955). Multiple Range and Multiple F-Tests. Biomettics, 11: 1-42.

Ebenebe, C.I.; Umegechi, C.O.A. and Nweze, B.O. (2012). Comparison of haematological parameters and weight changes of broiler chicks fed different levels of Moringa oleifera diet. Int. J. Agric. Biosci., 1: 23-25.

Fahey, J.W.; Zakmann, A.T. and Talalay, P. (2001). The chemical diversity and distribution of glucosinolates and isothiocyanaes among plants. Corrigendum Phytochem., 59: 200-237.

Google maps (2016).

Hassan, H.M.A; El-Moniary, M.M.; Hamouda, Y.; Eman, F.; Amani, W.Y. and Abd El-Azeem, N. (2016). Effect of different levels of Moringa oleifera leaves meal on productive performance, carcass characteristics and some blood parameters of broiler chicks reared under heat stress conditions. Asian J. Anim. Vet. Adv., 11(1): 60-66.

Jaiswal, D.; Kumar, R.P.; Kumar, A.; Mehta, S. and Watal, G. (2009). Effect of Moringaoleiferalam. leaves aqueous extract therapy on hyperglycemic rats. J. Ethnopharmacol., 123 (3): 392-396.

Kakengi A.M.V.; Kaijage J.T.; Sarwatt S.V.; Mutayoba S.K.; Shem M.N. and Fujihara, T. (2007). Effect of Moringaoleifera leaf meal as a substitute for sunflower seed meal on performance of laying hens in Tanzania. Livestock Res. Rural Develop., 19: 120. 
Kaplan, L.A., Pesce, A.J. and Kazmierczak, S.C. (2003). Liver Function. In: Sherwin, J.E. (Ed.), Clinical Chemistry, $4^{\text {th }}$ Ed., Elsevier Sci., St. Louis, Toronto.

Karthivashan, G., Arulselvan, P., Alimon, A., Ismail, I.S. and Sharida Fakurazi, S. (2015). Competing Role of Bioactive Constituents in Moringaoleifera Extract and Conventional Nutrition Feed on the Performance of Cobb 500 Broilers. BioMed. Res. Int., Article ID 970398, 13 pages.

Kout Elkloub, M.; Moustafa, E.R.; Shata, F.H.; Mousa, M.A.M.; Alghonimy, H.A.H. and Youssef, S.F. (2015). Effect of using moringaoleifera leaf meal on performance of Japanese quail. Egypt. Poult. Sci., (35):1095-1108.

Lee, K.W., Everts H. and Beynen A.C. (2004). Essential oils in broiler nutrition. Int. J. Poult. Sci., 3: 738-752.

Luqmans, S.; Srivastava, S.; Kumar, R.; Maurya, A.K. and Chanda, D. (2012). Experimental assessment of Moringa oleifera leaf and fruit for its antistress, antioxidant, and scavenging potential using in vitro and in vivo assays. Evidence-Based Complement. Altern. Med., 10:1155/2012/519084

Mahmud, M.A.; Peter, S.; Jame, G.; Ruth, N.; Wosilat, A.; Musa, M. and Abubakar, M.A. (2016). Growth Performance and Gastrointestinal Tract Morphometry in Growing Japanese Quails Fed with Moringa oleifera Leaf Meal as Partial Replacement of Dietary Soya Beans Meal. J. World Poult. Res., 6 (2): 92-98.

Makanjuola, B.A.; Obi, O.O.; Olorungbohunmi, T.O.; Morakinyo, O.A.; Oladele-Bukola, M.O. and Boladuro, B.A. (2014). Effect of Moringa oleifera leaf meal as a substitute for antibiotics on the performance and blood parameters of broiler chickens. Livestock Res. for Rural Develop., 26 (8).

Nkukwana, T.T.; Muchenje, V.; Pieterse, E.; Masika, P.J.; Mabusela, T.P.; Hoffman, L.C. and Dzama, K. (2014). Effect of Moringa oleifera leaf meal on growth performance, apparent digestibility, digestive organ size and carcass yield in broiler chickens. Livestock Sci., 161: 139-146.

NRC (1994). National Research Council. Nutrient Requirements of Rabbits. Washington, DC. USA.

Ologhobo, A.D.; Akangbe, E.I.; Adejumo, I.O. and Adeleye, O. (2014). Effect of Moringa oleifera leaf meal as replacement for oxytetracycline on carcass characteristics of the diets of broiler chickens. Ann. Res. and Rev. Biol., 4 (2): 423-431.

Paguia, H.M.; Paguia, R.Q.; Flores, R.C. and Balba, C.M. (2014). Utilization and evaluation of Moringa oleifera as poultry feeds. Monograph No. 11. Res. and Develop. Office, Bataan Peninsula State Univ. City Balanga, Philippines.

SAS (2004). SAS procedures Guide for personal Computers, Statistical Analysis Syst. Inst., Inc., Cary, N.C.

Siddhuraju, N.R.P. and Becker, K., (2003). Evaluation of nutritional quality of Moringa (Moringa oleifera Lam) leaves as an alternative source for Nile tilapia (Orechromis niloticus L.). Aquac., 217: 599-611.

Teteh, A.; Lawson, E.; Tona, K.; Decuypere, E. and Gbeassor, $M$. (2013). Moringa oleifera leave: hydroalcoholic extract and effects on growth performance of broilers. Int. J. Poult. Sci., 12 (7): 401-405.

Yang, Y.; Iji P.A. and Choct M. (2009). Dietary modulation of gut microflora in broiler chickens: A review of the role of six kinds of alternatives to in-feed antibiotics. World's Poult. Sci. J., 65: 97114. 
تأثير التفذية على مسحوق أوراق المورينجا أوليفيرا على الأداء الإنتاجي للسمان تحت ظروف شمال سيناء

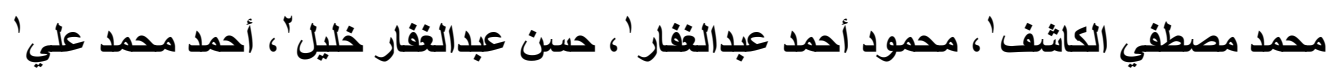

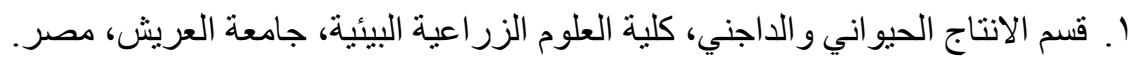

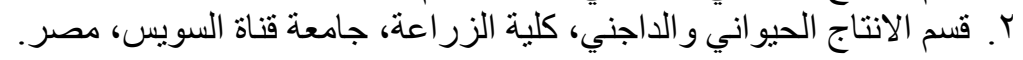

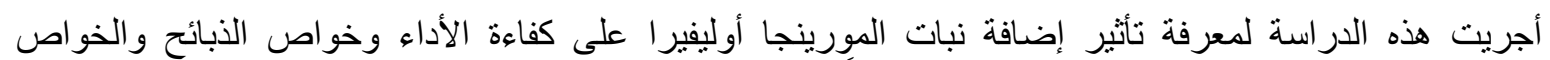

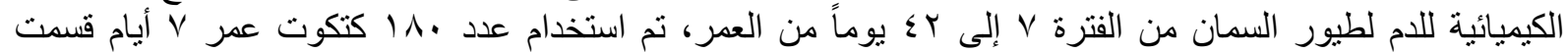

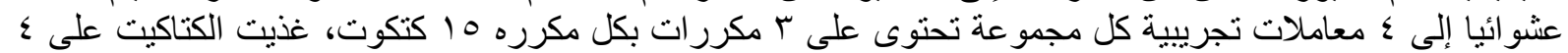

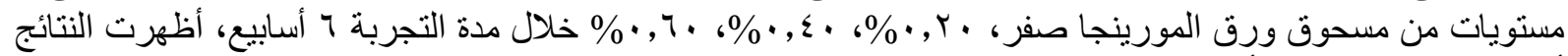

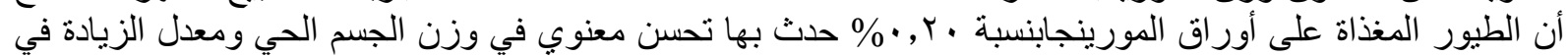

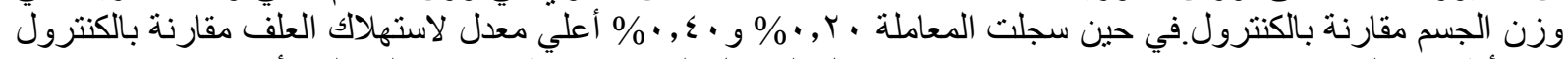

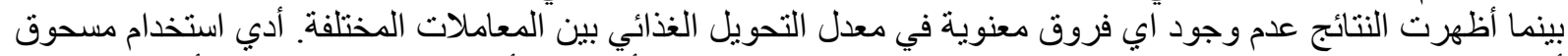

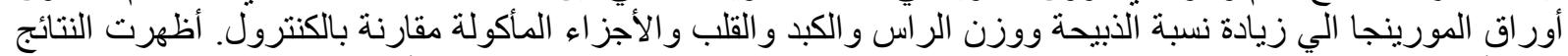

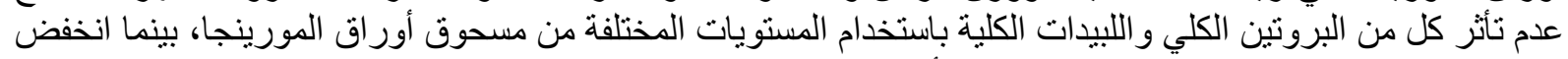

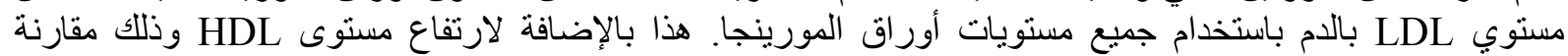

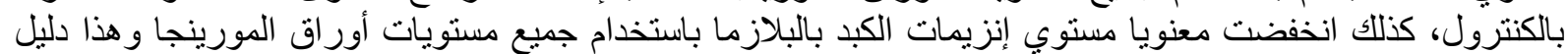

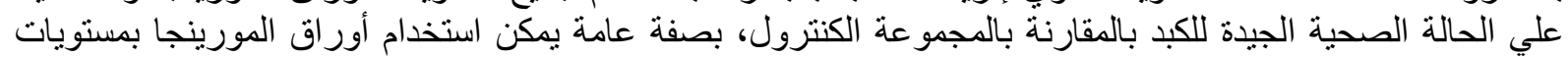

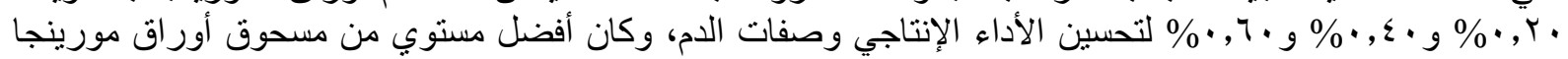

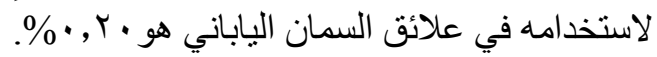
الكلمات الاسترشادية: مسحوق أور اق المورينجا أوليفير ا، الأداء الإنتاجي، السمان، ظروف هون شمال سيناء. 